\title{
Hubs and upstarts: pathways to urbanism in the northern Fertile Crescent
}

\section{Dan Lawrence \& T.J. Wilkinson*}

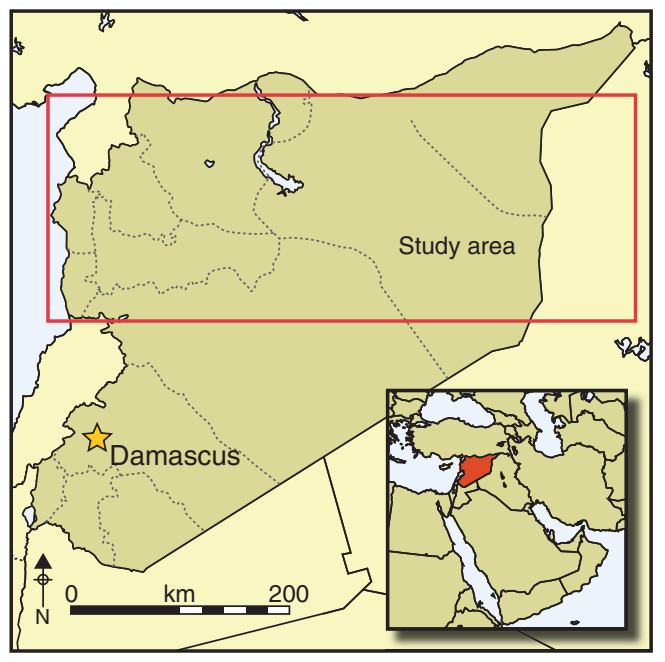

The origins of urbanism are a controversial subject, with neo-evolutionary progress through graduated stages of 'civilisation' still having significant influence despite criticism, while others in the field prefer more diverse, regionally based trajectories. Using data collected over 30 years and applying the full range of archaeological and historical sources, the authors offer an alternative reading of the evidence, identifying multiple pathways to urbanism within a single region-northern Mesopotamia. Here, early urbanism was a phased and pulsating phenomenon that could be sustained only within particular geographic parameters and for limited periods. Older urban hubs, growing slowly, were accompanied by rapidly expanding new sites, with the combination of the different forms demonstrating the complexities of urban growth.

Keywords: Fertile Crescent, Late Chalcolithic, Early Bronze Age, urbanism, tell, survey, database, regional exchange

\section{Introduction}

The development of large-scale urban centres has long been a research focus for archaeologists, especially in areas of the world where complex societies are considered to have arisen ex nihilis to form 'pristine' civilisations. A key debate in this research has centred on the efficacy of neo-evolutionary approaches to social change and their relationship with more historically contingent models. Neo-evolutionary theory argues that societies pass through defined stages of increasing complexity (bands, tribes, chiefdoms and states, although there may be significant sub-divisions and variations in terminology within each of these categories) in a process that is both unilinear and non-reversible. The central tenets of the theory are considered universal, allowing for the comparison and categorisation of

* Department of Archaeology, Durham University, South Road, Durham,DH1 3LE, UK(Email: dan.lawrence@ durham.ac.uk) 
all societies across both time and space, and resulting in the investigation of cross-cultural regularities at a global scale (Flannery 1999). This approach has come under sustained attack from scholars who highlight the variation in the types of complex society visible in the archaeological record and who reject the idea of a single trajectory of increasing complexity as both mechanistic and teleological (McIntosh 1999; Yoffee 2005; Blanton \& Fargher 2008). Rather than looking for cross-cultural 'laws' that are generally applicable, emphasis is instead placed on the unique nature of social and political developments in a given region over a particular period and, consequently, the variety of possible routes to different forms of 'complexity'. However, there is still a tendency among scholars to generalise at the regional level, so that we may talk of 'African states', 'Mesoamerican chiefdoms' or 'Mesopotamian cities' as sets of unified and uniform entities. More importantly, even within this literature, few explicit alternatives to neo-evolutionary models have been proposed.

This paper demonstrates the existence of multiple pathways to urbanised societies within northern Mesopotamia during the late fifth, fourth and third millennia BC, and it provides models through which these trajectories may be understood. We make use of excavation data, historical information derived from texts and archaeological surveys to examine the relationship between urban centres and their hinterlands through time. This approach draws on a growing body of theory that emphasises the relatively simple relationships that may exist for cities at a variety of different scales, focusing on population density, occupied areas and technological constraints (Fletcher 1995, 2004; Batty 2013; Bettencourt 2013). Evidence is drawn from surveys conducted over the past 30 years in the vicinity of a range of centres across the northern Fertile Crescent (Figure $1 \&$ Table 1). The approach is explicitly regional in scope and incorporates evidence from an area only slightly smaller than the United Kingdom, some $130000 \mathrm{~km}^{2}$, including a range of terrains, precipitation regimes and environmental circumstances.

\section{Emerging complexity in the Late Chalcolithic}

We can distinguish two phases of urbanisation in northern Mesopotamia during the period in question: firstly, during the Late Chalcolithic period (4400-3000 BC); and secondly, during the latter part of the Early Bronze Age (2600-2000 BC), punctuated by a period of ruralisation (Ur 2010b). Our understanding of the dynamics of settlement change in the Late Chalcolithic is hampered by the relatively unrefined chronological schema available. The most widely used ceramic chronology sub-divides the 1400-year period of the Late Chalcolithic into five phases, labelled LC 1-5 (Rothman 2001; Schwartz 2001). The majority of surveys conducted before the publication of the LC chronology did not subdivide the Late Chalcolithic beyond noting the presence of southern Mesopotamian Uruk types, which we now know to be restricted to the LC 4 and 5 phases. Given this chronological uncertainty, it is difficult to make nuanced statements about the nature of Late Chalcolithic urbanism. However, within this phase small-scale centres of between 10 and 20ha emerged, along with evidence for craft specialisation, monumental architecture and long-distance trade. Occasional sites of this size had existed before, notably at Domuztepe during the Halaf period (Carter et al. 2003) and Tell Zeidan and Tell al-Hawa during the Ubaid (Ball et al. 1989; Stein 2012), but by the Late Chalcolithic at least 10 sites across the region 


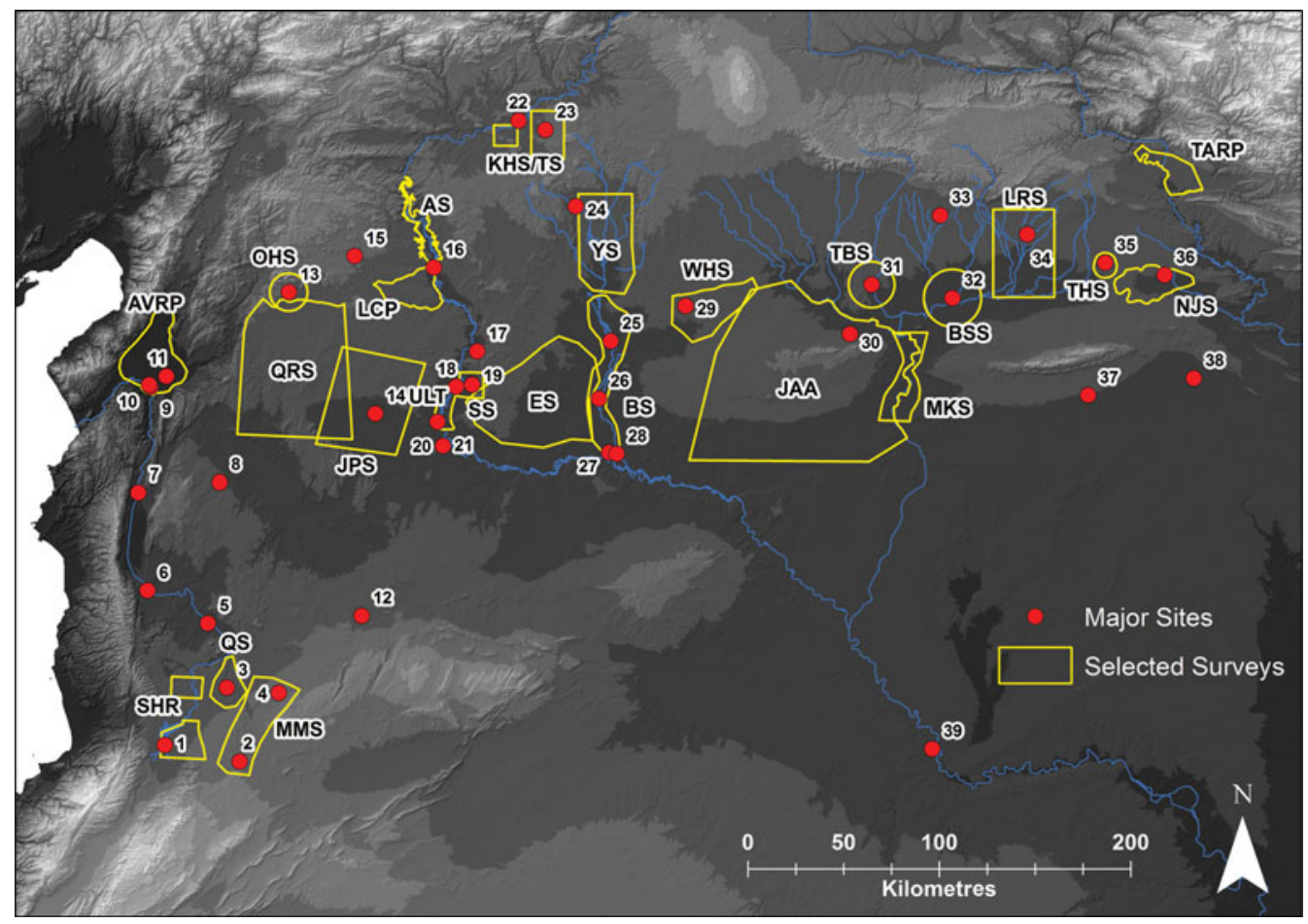

Figure 1. Sites and surveys used: 1) Nebi Mend; 2) Tell es-Sour; 3) Qatna; 4) Tell She'ir; 5) Hama; 6) Tell Aachane; 7) Tell Qarqur; 8) Ebla; 9) Tell Atchana; 10) Tell Táyinat; 11) Tell Imar; 12) Al-Rawda; 13) Oylum Höyük; 14) Umm el-Marra; 15) Tilbeshar; 16) Carchemish; 17) Tell Banat/Bazi; 18) Tell Hadidi; 19) Tell es-Sweyhat; 20) Selenkehiye; 21) Emar; 22) Samsat; 23) Titris Höyük; 24) Kazane Höyük; 25) Tell Hammam et-Turkman; 26) Tell es-Seman; 27) Tell Bia; 28) Tell Chuera; 29) Tell Zeidan; 30) Tell Mabtuh al-Sharqi; 31) Tell Beydar; 32) Tell Brak; 33) Tell Mozan; 34) Tell Leilan; 35) Hamoukar; 36) Tell al-Hawa; 37) Tell Khoshi; 38) Tell Taya; 39) Mari.

had reached 10ha. These sites are generally high tells or citadel mounds with steep sides, suggesting that they developed gradually through successive building phases. Three sites in the central and eastern Khabur Basin, however, reached much larger sizes, including Tell al-Hawa at 50ha (Ball et al. 1989), Tell Brak, initially 55ha during LC 1-2, growing to 130ha during the LC 3 and Uruk periods (Ur et al. 2011), and Khirbet al Fakhar at Tell Hamoukar, which might have been over $300 \mathrm{ha}$ and was at least 30ha during the early part of the period (Ur 2010a; Al-Quntar et al. 2011). All three of these sites included an occupational mound as well as wider scatters of dispersed settlement in the surrounding area.

Late Chalcolithic settlement is spatially discontinuous: sites are concentrated in a series of well-watered lowlands and basins along major rivers, with large swathes of intervening steppe and upland being more sparsely inhabited (Figure 2). With the exception of the Khabur Triangle, each basin contains a single 'centre'. Evidence from multiple archaeological surveys suggests an absence of settlement hierarchies of more than two tiers, with centres surrounded by a number of smaller sites of similar size and a gradual increase in settlement density over time. There is also a strong positive correlation between the size of the largest site within a (C) Antiquity Publications Ltd, 2015 
Table 1. Names and abbreviations of surveys mentioned in the text or included in the wider dataset. Note that where no formal project name is available surveys have been labelled after their director or central site with their geographic location in parentheses.

\begin{tabular}{ll}
\hline Survey name & Abbreviation \\
\hline & \\
Birecik Dam Survey & AS \\
Amuq Valley Regional Project & AVRP \\
Balikh Survey & BS \\
Einwag Survey & ES \\
Jabbul Plain Survey & JPS \\
Jebel Abd al-Aziz Survey & JAA \\
Kurban Höyük Survey and Titris Höyük Survey (combined) & KHS/TS \\
Land of Carchemish Project & LCP \\
Leilan Regional Survey & LRS \\
Maqdissi Survey (West Syrian Steppe) & MS \\
Middle Khabur Survey & MKS \\
North Jazira Project & NJP \\
Oylum Höyük Survey & OHS \\
Qatna Survey & QS \\
Sites and Monuments in the Homs Region & SHR \\
Tell Beydar Survey & TBS \\
Tell Brak Sustaining Area Survey & BSS \\
Tell es-Sweyhat Survey & SS \\
Tell Hamoukar Survey & THS \\
Tell Rifa'at Survey (Qoueiq Plain) & QRS \\
Tigris-Euphrates Archaeological Reconnaissance Project (Cizre-Silopi Plain) & TARP \\
Upper Lake Tabqa Survey & ULT \\
Wadi Hammar Survey & WHS \\
Yarmdici Survey (Harran Plain) & YS \\
\hline
\end{tabular}

survey and the density of occupation in the surrounding landscape (Figure 3). These data are computed by dividing the published site counts from each survey by the area of the survey, which is in turn adjusted to compensate for the differences in the length of the Late Chalcolithic phases used (Wilkinson et al. 2014). This model helps to mitigate the 'problem of contemporaneity', where longer phases result in the amalgamation of successive settlement patterns (Ammerman 1981; Schact 1984). If we take settlement density as a proxy for population density, this pattern has significant consequences for understanding early urban development. Most clearly, it suggests a relationship between population size and urban growth that holds for both the relatively small centres and the three larger centres in the Jazira. The three largest sites, Tell Brak, Khirbet al Fakhar and Tell al-Hawa, may therefore result from the same sorts of processes as the smaller centres.

High population density reduces the 'costs' of social interaction, as the physical distance between individuals is necessarily decreased (Drennan \& Peterson 2012). This holds true regardless of the specific form such interaction takes, and it therefore includes negative interactions such as conflict and warfare, as well as more positive collective action and movements of goods and ideas. Evidence for conflict during this period comes from mass 


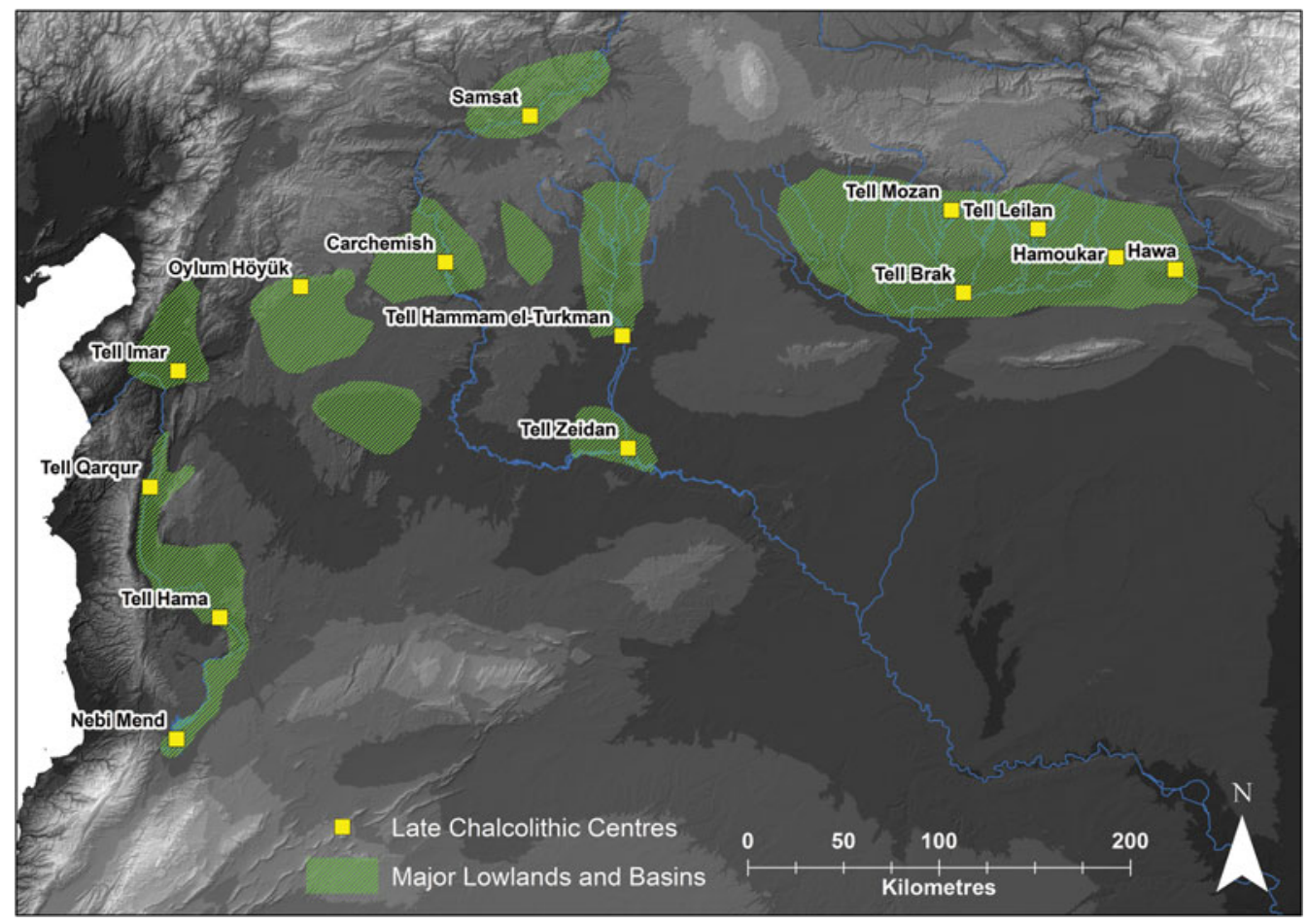

Figure 2. Location of Late Chalcolithic sites and major agricultural basins.

graves at Tell Brak (McMahon et al. 2011) and destruction levels at Tell Hamoukar (Reichel 2009). However, the longevity of the Late Chalcolithic centres contradicts models that rely on conflict alone as the prime mover in urban development as argued by Carneiro (1970) and Flannery (1999). If we assume that a higher population density results in higher levels of conflict, we would expect greater instability in the settlement pattern as different individuals and groups became dominant. As well as local competition resulting in conflict and violent incorporation of territory and population, we argue that the larger centres that emerged in the Late Chalcolithic were a response to regional level exchange networks and competition (Stein 2012). Many Late Chalcolithic centres are situated at locations favourable for controlling both long-distance movement and the dissemination of goods in their local area, while those in the Khabur and north-western Iraq are situated within a dense network of hollow-way routes that, although primarily of Early Bronze Age date, were probably developing in the Late Chalcolithic (Wilkinson et al. 2010). Both Khirbet al Fakhar and Tell Brak were centres for the trade and manufacture of obsidian derived from the Anatolian highlands (Khalidi et al. 2009; Al-Quntar et al. 2011). Other prestige goods, including lapis lazuli from Afghanistan, copper and chlorite from southern Turkey and cowrie shells from the Mediterranean, were also in circulation in a highly integrated regional system (Stein 2012). At the same time, evidence of large-scale feasting from trench TW at Tell Brak and at Arslantepe in Anatolia may be interpreted as an integrative strategy

(C) Antiquity Publications Ltd, 2015 


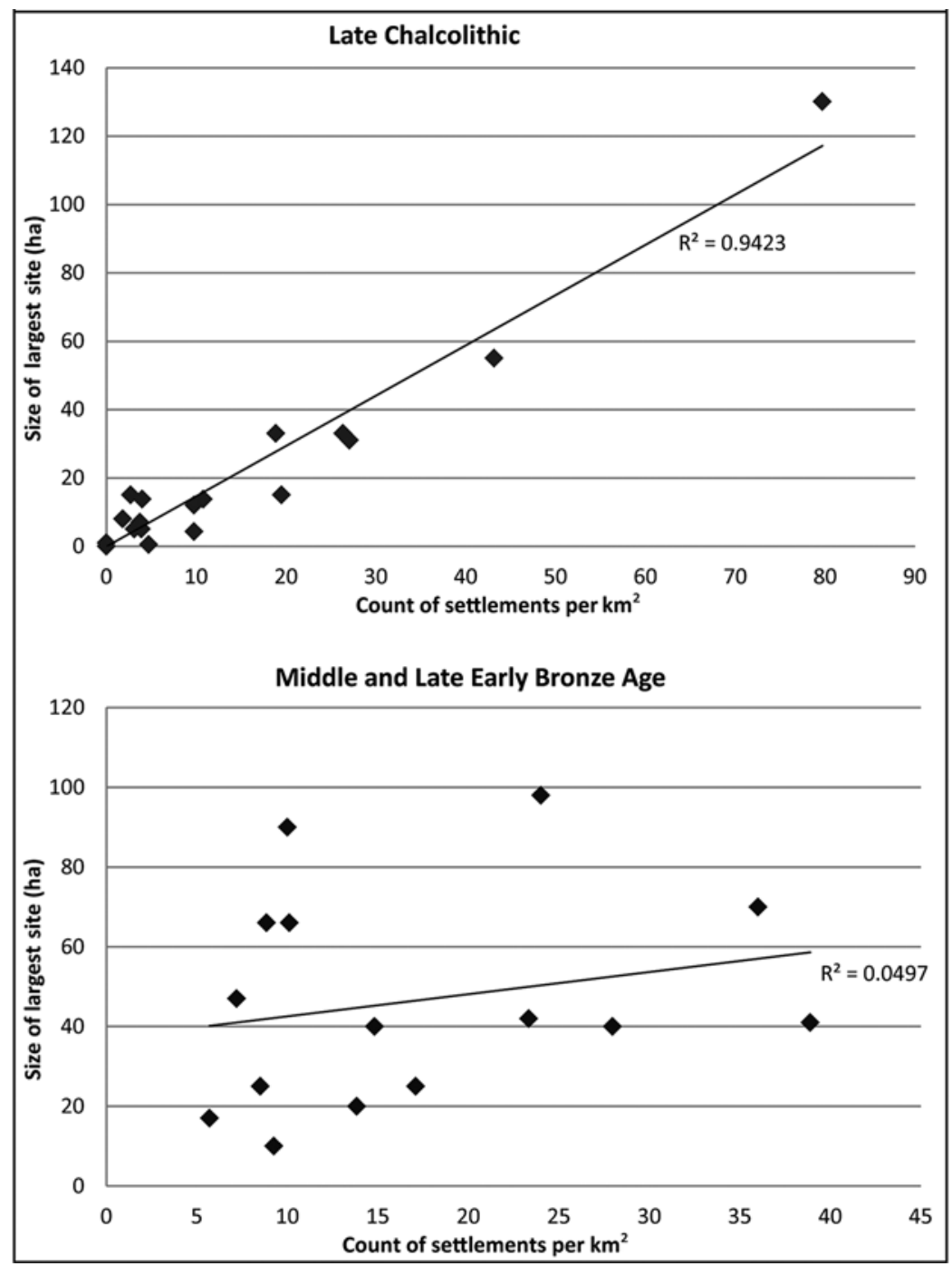

Figure 3. Scatter plots showing size of largest site in survey against number of settlements per $\mathrm{km}^{2}$.

of social bonding performed by local elites (Emberling \& McDonald 2001; D'Anna \& Guarino 2010). We could characterise the Late Chalcolithic centres, therefore, as hubs in both regional exchange and local political networks.

\section{Rapid urban development in the Early Bronze Age}

The later phase of urbanisation, commonly termed the 'second urban revolution', included "the full-fledged adoption of urban life and its associated institutions" (Akkermans \& Schwartz 2003: 233). 'Urban' centres of between 40 and 120ha, several times larger than the modal Late Chalcolithic centre, emerged across the northern Fertile Crescent to include 


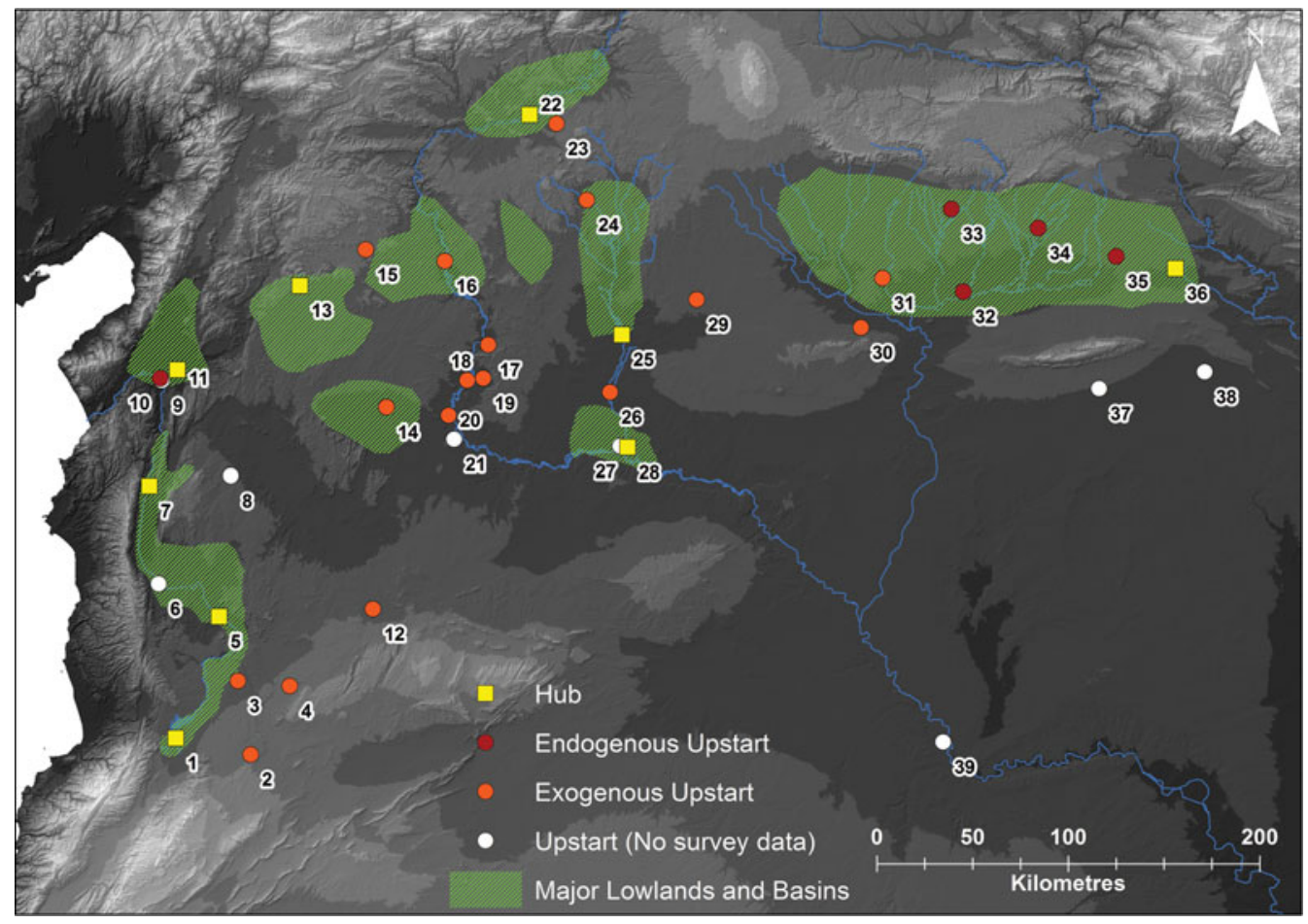

Figure 4. Hub and upstart sites across the northern Fertile Crescent: 1) Nebi Mend; 2) Tell es-Sour; 3) Qatna; 4) Tell She'ir; 5) Hama; 6) Tell Aachane; 7) Tell Qarqur; 8) Ebla; 9) Tell Atchana; 10) Tell Ta'yinat; 11) Tell Imar; 12) Al-Rawda; 13) Oylum Höyük; 14) Umm el-Marra; 15) Tilbeshar; 16) Carchemish; 17) Tell Banat/Bazi; 18) Tell Hadidi; 19) Tell es-Sweyhat; 20) Selenkehiye; 21) Emar; 22) Samsat; 23) Titris Höyük; 24) Kazane Höyük; 25) Tell Hammam et-Turkman; 26) Tell es-Seman; 27) Tell Bia; 28) Tell Chuera; 29) Tell Zeidan; 30) Tell Mabtuh al-Sharqi; 31) Tell Beydar; 32) Tell Brak; 33) Tell Mozan; 34) Tell Leilan; 35) Hamoukar; 36) Tell al-Hawa; 37) Tell Khoshi; 38) Tell Taya; 39) Mari.

large public buildings, city walls, and evidence for social differentiation and the mass production of goods such as pottery, stone tools and textiles. Writing also appeared in the region for the first time during the later Early Bronze Age (2600-2000 BC), allowing the reconstruction of political events and socio-economic organisation. The Early Bronze Age urban centres differ from those of the Late Chalcolithic in size, spatial organisation, settlement layout and developmental trajectories. While the Khabur triangle remained a locus of settlement, with sites such as Tells Hamoukar, Mozan and Leilan reaching in excess of 90ha, similar sites grew up in the Euphrates Valley and the plains to the east and west, resulting in a more even distribution (Figure 4).

Three-tiered site hierarchies are visible in some areas, such as the North Jazira and Karababa dam surveys, but are by no means universal. In contrast to the Late Chalcolithic, there is no clear relationship between settlement density around a centre and the size of that centre (Figure 3), suggesting that regional population density was not a significant factor in urban development. A further difference between the urbanisation process in the Late Chalcolithic and the Early Bronze Age is that the latter appears to have been rapid, occurring within 200-300 years during the middle of the third millennium BC.

(C) Antiquity Publications Ltd, 2015 

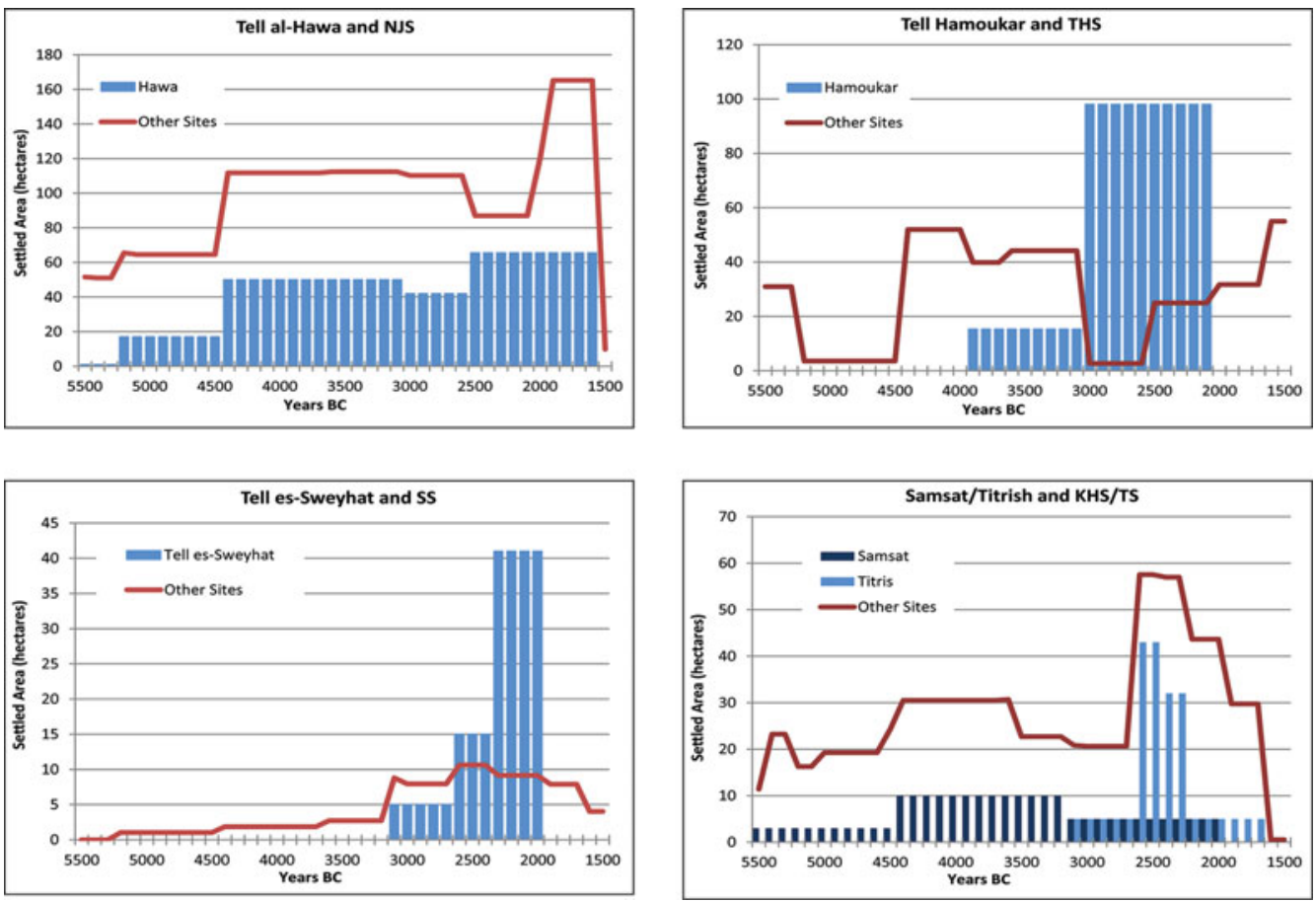

Figure 5. Size of urban centre and combined settled area of hinterland survey for the period between 5500 and $1500 B C$ for five sample surveys.

The decline of these settlements was similarly rapid and has been attributed to a variety of factors, including catastrophic climate change (Weiss 1997), structural instability in food provision (Wilkinson 1994), insecurity as a result of invasions from southern Mesopotamia (Sertok et al. 2007) and new cultural groups (Wossink 2009). We have labelled these types of settlement 'upstarts' due to the speed of their initial expansion and what appear in some cases to be their counterintuitive locations.

\section{Urbanism as a process: comparative settlement trends}

The divergent modes of urban development in the Late Chalcolithic and Early Bronze Age can be investigated by comparing the relationship between urban centres and their surrounding rural settlement. Here, we employ a series of intensive surveys conducted over the past 30 years contained within the database of the Fragile Crescent Project at Durham University. These surveys used similar methods, allowing us to circumvent some of the common problems in the comparison of survey datasets (Alcock \& Cherry 2004); together, they provide a broad sample coverage of regional settlement. Unfortunately, there are differences in the precision of the ceramic chronologies used in each survey. In order to display the data in the same format, we used the Fragile Crescent Project database to convert each phase into time blocks of 100 years (see Lawrence 2012; Lawrence et al. 2012). Figure 5 shows the relationship between the size of five large sites (columns) and the total combined 


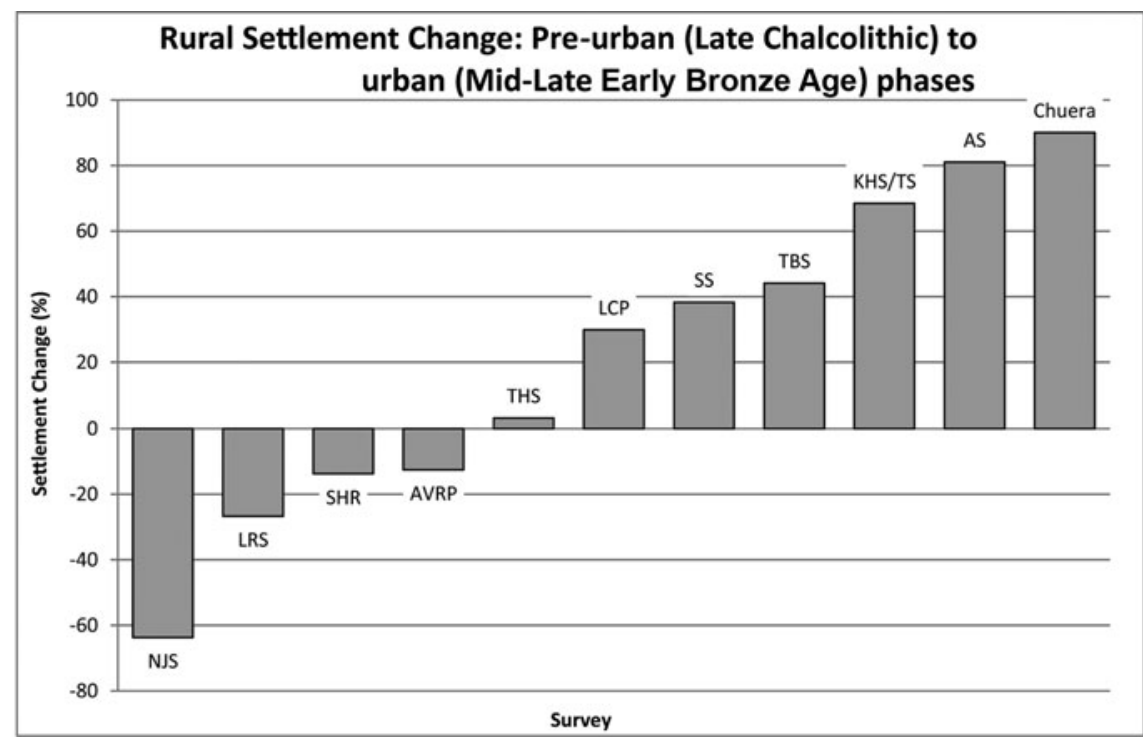

Figure 6. Percentage change in hinterland settled area in the pre-urban (Late Chalcolithic) and urban (Mid-Late Early Bronze Age) phases for all surveys containing Early Bronze Age centres.

occupied area of all of the other sites in the surveys carried out around them (lines). The surveys surrounding Samsat and Titrish Höyüks in the Karababa region (Figure 1) have been combined because they overlap and are spatially contiguous. The difference between the long-lived Late Chalcolithic sites represented by Tell al-Hawa and Samsat and the rapid expansions and contractions at Tell Hamoukar, Tell Sweyhat and Titrish Höyük is immediately clear. Although there appears to be an increase in rural population at the end of the Ubaid, the Late Chalcolithic itself is quite stable. Settlement around the Early Bronze Age urban centres is rather more volatile. In the Tell Hamoukar Survey, rural settlement declined dramatically at the same time as the expansion of Tell Hamoukar, suggesting that local populations might have been drawn into the emerging centre. In fact, the pull of Tell Hamoukar might have extended into the adjacent North Jazira Project survey area where the western half of the survey area was abandoned. Sweyhat and Titrish exhibit precisely the opposite trend: growth at the centre coincided with growth in the hinterland.

We can examine this trend at a regional level for the later Early Bronze Age by comparing the percentage change in rural settlement from the pre-urban phase to the urban phase for all of the surveys that included an Early Bronze Age urban centre (Figure 6). It is clear from these data that two fundamentally different types of centre are visible: those in which settlement decreased, or remained unchanged, through the urbanisation process and those in which the expansion of the largest site coincided with an expansion in rural settlement.

Within the category of 'upstarts', we therefore recognise a further sub-division between centres that could have expanded through the reorganisation of their local settlement pattern and those that must have required external population reservoirs to sustain their growth. We call these endogenous upstarts and exogenous upstarts. Quite where these populations

(C) Antiquity Publications Ltd, 2015 
might have been coming from requires more research, but it is notable that very few surveys report a decline in settlement during the later Early Bronze Age. One exception to this is a recently published survey of the Cizre-Silopi plain in the Upper Tigris region to the north of the Khabur Basin, which does experience a significant decline in settlement (Algaze et al. 2012). It is possible that certain under-surveyed areas, such as the foothills of the Taurus mountain range, might have experienced population decline as people moved into the plains and steppe to the south, but more data are required to test this hypothesis.

The spatial distribution of the two types of upstart provides the starting point for a model of their development. Endogenous upstarts are located in the same fertile basins as the Late Chalcolithic hubs; in fact, some hub sites, such as Tell Leilan, became enlarged upper towns for the Early Bronze Age cities. Exogenous upstarts, by contrast, are located in previously marginal areas, especially in the steppe, where subsistence based solely on rain-fed agriculture carries a greater risk (Smith et al. 2014). Moreover, the later part of the Early Bronze Age across the northern Fertile Crescent saw a substantial expansion of settlement into more marginal environments. This process was linked to changes in agricultural practices, animal husbandry and social organisation (Lawrence 2012; Wilkinson et al. 2014). The widespread uptake of wool-bearing sheep and the attendant trade in textiles meant large tracts of land that could not be used to support agriculture reliably became productive, whereas land in more fertile areas that had previously been used to grow flax became available for other crops. This 'fibre revolution' might have resulted in an economic boom, but it must have had profound social implications for labour organisation, specialisation and perhaps gender roles (McCorriston 1997), while the development of institutions capable of bearing and manipulating the risks inherent in practising agriculture in more marginal environments might also have played a role (Wilkinson et al. 2012). The transportable nature of both sheep and goat flocks and manufactured textiles would have allowed for trade and exchange on a scale altogether different from that seen in earlier periods. A key constraint in the development of urbanism in northern Mesopotamia compared with that in southern Mesopotamia might have been the inability to transport bulk staple products such as cereals, due to the lack of navigable canals (Algaze 2005, 2008). Large-scale sheep and goat herding, the commodification of durable lightweight textiles and the widespread use of equids as pack animals, first domesticated in the fourth millennium (Grigson 1995, 2006: 233), provided a less efficient alternative to waterborne trade in staples.

\section{Urban morphology in the Early Bronze Age}

The distinction between endogenous and exogenous upstarts is all the more significant because, once established, both types exhibit similar formal properties in urban morphology and landscape signature. In contrast to the gradually developing high mounds of the Late Chalcolithic, the Early Bronze Age centres, which included a small upper town and an extensive fortified lower town, account for the vast majority of the new 'urban'-sized settlements (Figure 7). In general, upper towns were occupied in preceding periods, and in some cases might have been reasonably sized settlements prior to the Early Bronze Age expansion. For example, the step trench at Tell Leilan revealed a sequence dating back to at least the early part of the Late Chalcolithic (Schwartz 1988). 


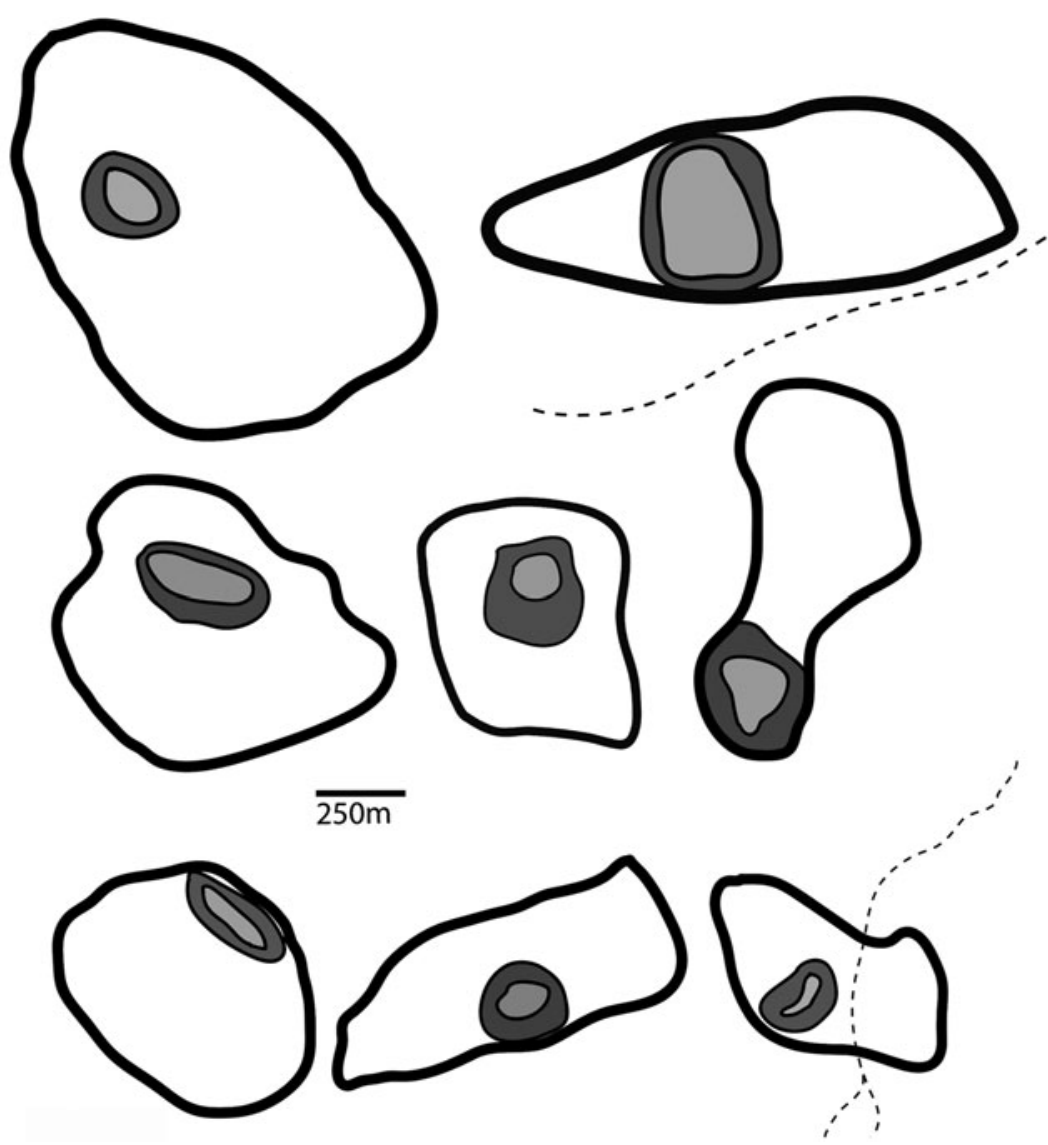

Figure 7. Schematic outlines of several Early Bronze Age centres. Black lines represent city walls, dark grey shows the bottom of tell, light grey illustrates the top of tell. From top left to bottom right: Kazane Höyük; Tell Hadidi; Tilbeshar; Tell es-Sweyhat; Tell Banat/Bazi; Carchemish; Titris Höyük and Tell es-Seman.

Tell Hamoukar, Tell Mozan and Carchemish have also revealed similar LC 3 layers, along with isolated Ubaid and even Halaf sherds (Woolley 1934; Buccellati \& Kelly-Buccellati 1988; Gibson et al. 2002), whereas Tell es-Sweyhat and Titrish Höyük were founded in the first half of the Early Bronze Age (Zettler 1997; Algaze et al. 2001). Once expansion had occurred, these tells became the focal part of the settlement, often including palaces and other monumental buildings. Lower towns have attracted less archaeological attention, and it is unclear to what degree these new areas of occupation resulted from the emergent logic of simultaneous settlement by a large number of people or, as some have argued, the imposition of a unified urban plan by elites or institutions (Meyer 2007; Ristvet 2011). Excavation and geophysical prospection reveal dense occupation and a certain amount of organisation, particularly visible in patterns of long-lived avenues or streets (Nishimura 2008; Creekmore 2010; Pfälzner 2010). We also know from later textual sources that the inhabitants of both northern and southern Mesopotamian cities had a clear conception of their own urban environment, which included upper and lower cities and fortification walls, (C) Antiquity Publications Ltd, 2015 
all of which had individual names (Van de Mieroop 2007 [1997]; Rey 2012). This does not preclude a model in which growth occurred as a piecemeal or random process, but it is probably more appropriate to speak of degrees of urban planning (Smith 2007) rather than a simple emergent-versus-planned dichotomy. In the context of the low-density urbanism of the lowland Maya, Christian Isendahl used the term "planned organic growth" to articulate the idea of "intentional convention" in urban form (Isendahl 2012: 1122). Applying this concept to the densely occupied lower towns of the northern Fertile Crescent, we suggest that pragmatic and functional choices in house location made at an individual or household level by large numbers of new settlers led to a coordinated system of local rules. Once in place, the built environment, land tenure and property rights were key structuring principles in the ongoing development of the city as a whole.

\section{Discussion: multiple pathways to urbanism}

It has been argued that the growth of urban centres in the northern Fertile Crescent was constrained by a size ceiling of around 100ha (Wilkinson 1994), later revised to 120ha by Stein (2004). This ceiling, and its estimated population, could be supported by the modelled agricultural yields from the centre and its surrounding settlements, along with the attendant transport costs in moving bulk volumes of staple products. The 100 ha figure is also cited by Roland Fletcher as an 'operational ceiling' for agrarian urban centres in general (Fletcher 1995). The above data suggest that urban sites could not transgress the 100-120ha 'operational ceiling' without significant changes in organisation or increased risk of instability and size reduction. Tell Brak exceeded the limit by some 10 ha during the second half of the Late Chalcolithic, while Khirbet al Fakhar might have reached 300ha. However, the surface collection evidence from both Tell Brak and Khirbet al Fakhar reveal a pattern of dispersed clusters of settlement unlike either the high-mounded Late Chalcolithic hubs or the contiguous upper and lower town formations of the Early Bronze Age upstarts, and neither site maintained this size for more than a few hundred years. However, below this 'urban' ceiling, broad categories can be distinguished based on differences in their rate of growth and the source of the population for that growth.

Of the three distinct pathways that resulted in the development of urban centres (Figure 8), slow-growing hub sites appear to have emerged over the course of a millennium or more in areas of dense and gradually increasing local population. In contrast to the hubs, both categories of upstart developed and declined rapidly in a cycle of boom and bust. In the case of endogenous upstarts, growth appears to have resulted from a reorganisation of local populations, with individuals being drawn to the cities from the surrounding villages. This local source of population was not available to the exogenous upstarts, which were predominantly located in areas with very little pre-existing settlement and must therefore have relied on external sources of population.

If, as in most citadel cities, the tell formed a pre-expansion settlement of Late Chalcolithic or early Early Bronze Age date, the ratio of the tell area to total site area provides a rough proxy for the degree of expansion of the site. The bi-axial plot shows Early Bronze Age citadel cities with a small tell and a large total site area within the darker shaded area (Figure 9). In contrast, slow-growing Late Chalcolithic hubs occupy a domain in which site size did not 


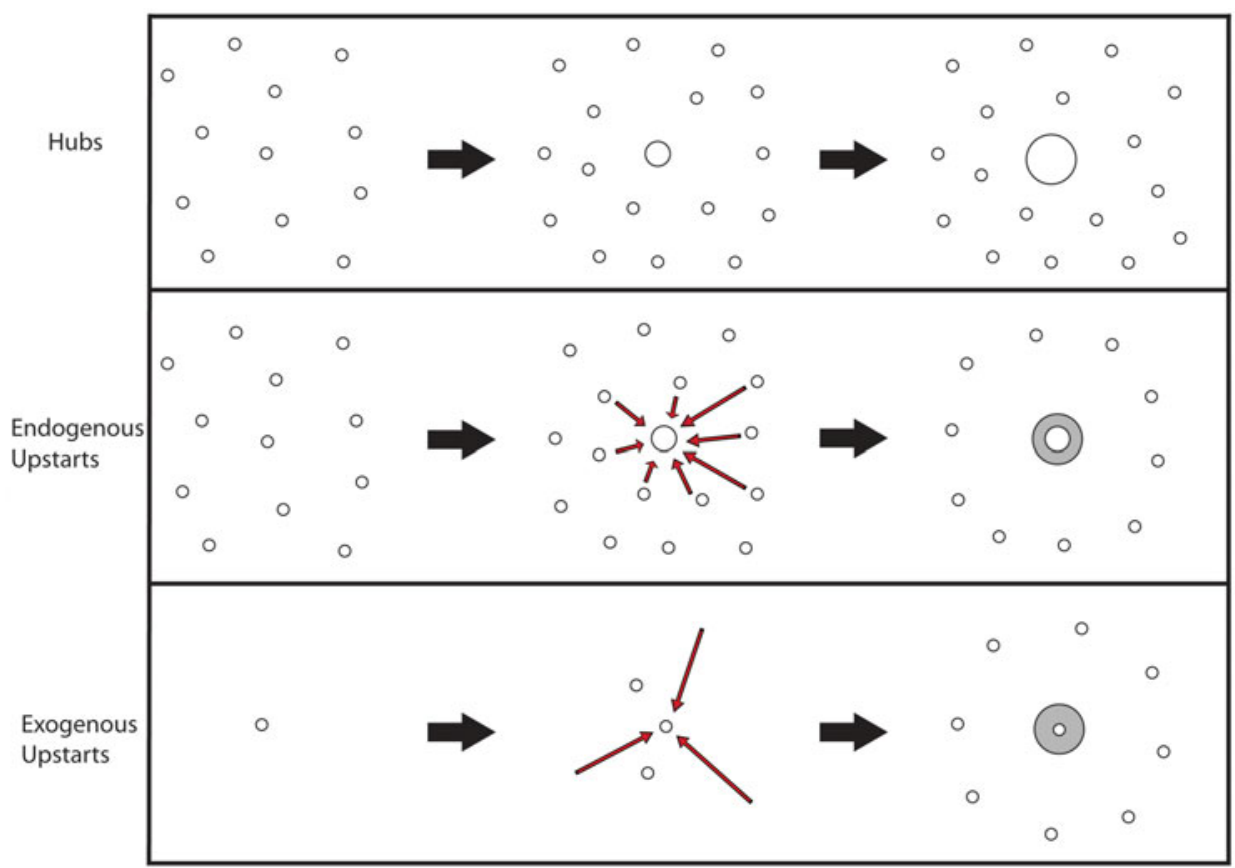

Figure 8. Schematic representation of three major pathways to urbanism in the northern Fertile Crescent. Small dots represent tell sites, dark grey represents lower towns, red arrows represent population movements.

exceed 55ha, although occasionally these exhibit rapid expansions as with LC 3-4 Brak (Ur et al. 2011; located by arrow on Figure 9). In contrast to Early Bronze Age citadel cities, large Late Chalcolithic tells, which continued to grow slowly and which lack evidence of a lower town, usually exhibit a small but relatively constant ratio between tell area and total area (steady growth, lighter shaded area, Figure 9). Although this concept provides only an approximation for the degree of settlement expansion, it illustrates an envelope of behaviours ranging from slow growth in the Late Chalcolithic, through to explosive growth as at LC 3-4 Brak and Hawa and in the Early Bronze Age citadel cities. The chart also accommodates the large number of small, relatively stable tells that dominate the Fertile Crescent landscape (Wilkinson et al. 2012), as well as new foundations that lack tells (not plotted on Figure 9, but occurring in the narrow void to the left). Phases of expansion off the tell, usually of 200-300 years and rarely more than 500-600 years duration, suggest that urbanisation was pulsating rather than gradual. The rare phases of explosive growth in the Late Chalcolithic become more common and formalised in the later third millennium BC.

The 55ha area of Tell Brak in LC 2 represents a ceiling for the maximum size of steady settlement growth. If settlement population was in the range of 100-150 persons per hectare, the estimated site population of 5500-8250 people would require a cultivated territory of some $4.2-5.1 \mathrm{~km}$ radius, a figure that approximates to a local agricultural territory in which cultivation could be conducted entirely from the central settlement. This would also be the case if settlement was limited to the main mound, some 40 ha, which, with a radius of cultivation of $3.6-4.4 \mathrm{~km}$, would again be potentially self-sufficient. Higher population (C) Antiquity Publications Ltd, 2015 


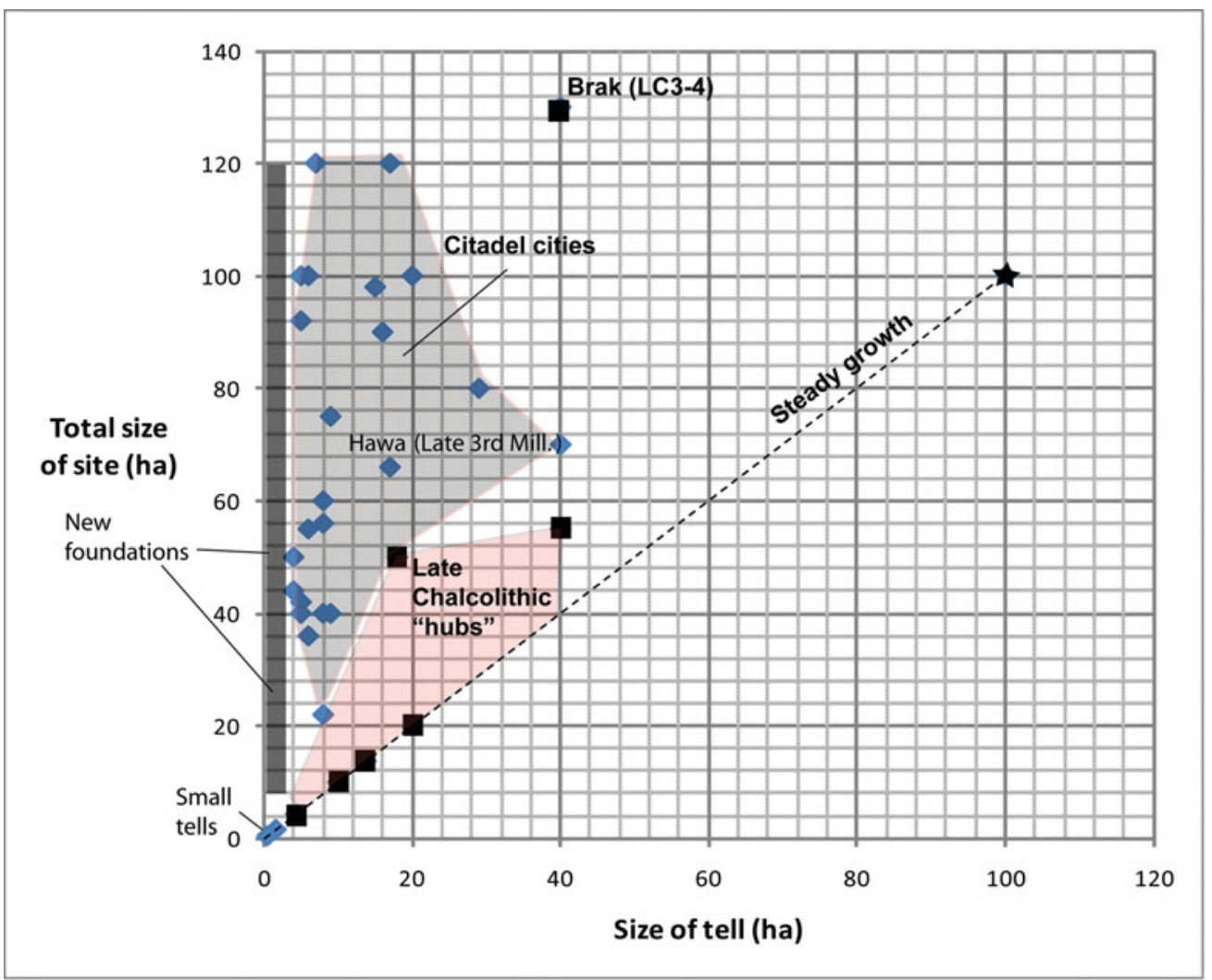

Key: - Late Chalcolithic hubs

Line representing the points where both tell \& expanded site are the same size (taken as roughly steady growth)

\section{Early Bronze Age citadel cities and expanded settlements}

Figure 9. Scatter plot of total size of settlement against size of mounded tell part of settlement.

densities, or sites larger than $55 \mathrm{ha}$, would not be sustainable within a single walking-distance territory. Significant expansion of settlement beyond the tell would probably correspond to a shift to a more complex political economy dependent upon staple contributions from outlying communities and a reliable transport infrastructure. Such a shift from a central tell to an expanded outer town, being dependent upon the incorporation of outlying communities into a growing polity created by ambitious kings or chiefs, would be inherently unstable, hence the evidence for pulsating growth.

\section{Conclusion}

Early urbanisation in the northern Fertile Crescent cannot be shoehorned into a single process; variations are evident based upon site morphology and the context of local 
settlement. The initial phase of urbanisation began with slow-growth 'hub' sites that, as self-supporting entities within a local catchment, may be best thought of as agro-towns rather than cities proper. The second phase of urbanisation involved the development of a series of 'upstarts', cities that grew rapidly and shared a distinctive upper and lower town morphology as a result, and that required shifts in population of different kinds. Throughout these processes there appear to have been limitations on the form and scale of growth. Late Chalcolithic towns were not sustainable when their population rose beyond that which could be supported by the immediately surrounding area. This limitation appears to have been circumvented during the Early Bronze Age through new forms of political and economic organisation that allowed cities to become integrated into wider networks. However, the urbanisation 'moment' in the Early Bronze Age was relatively brief and, again, the cities involved could not sustain themselves in the long term. Urban formation appears to have been a pulsating phenomenon that required levels of political, social and economic complexity and integration that could not be sustained for long periods.

\section{Acknowledgements}

We thank Graham Philip and the members of the Fragile Crescent Project at Durham University, as well as participants in the Durham Early Urbanism Seminar, for discussion and comments. Thanks are also given to the Arts and Humanities Research Council (grant no. AH/FO10095/1: Fragile Crescent Project), the British Academy and Council for British Research in the Levant (CBRL) for funding. We are very grateful to the Syrian Directorate General of Antiquities and Museums for supporting our various field projects. Timothy Matney and an anonymous reviewer provided useful suggestions for the final manuscript.

\section{References}

AKkermans, P.M.M.G. \& G. SCHWARTZ. 2003. The archaeology of Syria: from complex hunter-gatherers to early urban societies (ca. 16,000-300 BC). Cambridge: Cambridge University Press.

Alcock, S. \& J. Cherry (ed.). 2004. Side-by-side survey: 1-12. Oxford: Oxbow Books.

Algaze, G. 2005. The Sumerian takeoff. Structure and Dynamics 1(1): 3-41.

- 2008. Ancient Mesopotamia at the dawn of civilization: the evolution of an urban landscape. Chicago (IL): University of Chicago Press.

Algaze, G., G. Dinckan, B. Hartenberger, T. Matney, J. Pournelle, L. Rainville, S. Rosen, E. Rupley, D. SCHLEe \& R. VAllet. 2001. Research at Titriş Höyük in southeastern Turkey: the 1999 season. Anatolica 27: 1-84.

Algaze, G., E. Hammer \& B. Parker. 2012. The Tigris-Euphrates archaeological reconnaissance project. Final report of the Cizre Dam and Cizre-Silopi Plain survey areas. Anatolica 38: 1-115.

Al-Quntar, S., L. Khalidi \& J. UR. 2011. Proto-urbanism in the late $5^{\text {th }}$ millennium BC: survey and excavations at Khirbat al-Fakhar/Hamoukar, northeast Syria. Paléorient 37: $151-75$.

(C) Antiquity Publications Ltd, 2015
Ammerman, A.J. 1981. Surveys and archaeological research. Annual Review of Anthropology. 10: 63-88. http://dx.doi.org/10.1146/annurev.an.10. 100181.000431

Ball, W., D. Tucker \& T.J. Wilkinson. 1989. The Tell al-Hawa project: archaeological investigations in the North Jazira 1986-1987. Iraq 51: 1-66.

BATTY, M. 2013. A theory of city size. Science 340: 1418-19. http://dx.doi.org/10.1126/science. 1239870

BetTEnCOURT, L. 2013. The origins of scaling in cities. Science 340: 1438. http://dx.doi.org/10.1126/science. 1235823

BLANTON, R.E. \& L.F. FARGHER. 2008. Collective action in the formation of pre-modern states. New York: Springer. http://dx.doi.org/10.1007/978-0-387-73877-2

BucCellati, G. \& M. Kelly-BuCCEllati. 1988. Mozan I: the soundings of the first two seasons. Malibu (CA): Undena.

CARneiro, R.L. 1970. A theory of the origin of the state. Science 169: 733-38. http://dx.doi.org/10.1126/science.169.3947.733

Carter, E., S. Campbell \& S. Gauld. 2003. Elusive complexity: new data from Late Halaf Domuztepe in south-central Turkey. Paléorient 29: 117-34. http://dx.doi.org/10.3406/paleo.2003.4768 
Creekmore, A. 2010. The structure of Upper Mesopotamian cities: insight from fluxgate gradiometer survey at Kazane Höyük, south-eastern Turkey. Archaeological Prospection 17: 73-88.

D’AnNa, M.B. \& P. Guarino. 2010. Continuity and changes in the elite food management during the $4^{\text {th }}$ millennium BC. Arslantepe periods VII and VI A: a comparison, in M. Frangipane (ed.) Economic centralisation in formative states. The archaeological reconstruction of the economic system in $4^{\text {th }}$ millennium Arslantepe: 193-204. Rome: Sapienza Università di Roma.

Drennan, R.D. \& C.E. Peterson. 2012. Challenges for comparative study of early complex societies, in M.E. Smith (ed.) The comparative archaeology of complex societies: 62-87. Cambridge: Cambridge University Press.

Emberling, G. \& H. McDonald. 2001. Excavations at Tell Brak 2000: preliminary report. Iraq 63: 21-54.

FlanNERY, K.V. 1999. Process and agency in early state formation. Cambridge Archaeological Journal 9(1): 3-21. http://dx.doi.org/10.1017/ S0959774300015183

FLETCHER, R. 1995. The limits of settlement growth: a theoretical outline. Cambridge: Cambridge University Press.

- 2004. Materiality, space, time and outcome, in J. Bintliff (ed.) The Blackwell companion to archaeology. Oxford: Blackwell.

Gibson, M., A. Al-Azam, C.D. Reichel, S. Al-Quntar, J. Franke, L. Khalidi, C. Hritz, C. Coyle, C. Colantoni, J. Tenney, G. Abdul AzIz \& T. HARTNELL. 2002. Hamoukar: a summary of three seasons of excavation. Akkadica 123: 11-34.

Grigson, C. 1995. Plough and pasture in the early economy of the southern Levant, in T.E. Levy (ed.) The archaeology of society in the Holy Land: 245-68. Leicester: Leicester University Press.

- 2006. Farming? Feasting? Herding? Large mammals from the Chalcolithic of Gilat, in T.E. Levy (ed.) Archaeology, anthropology and cult: the sanctuary at Gilat, Israel: 215-319. London: Equinox.

IsENDAHL, C. 2012. Agro-urban landscapes: the example of Maya lowland cities. Antiquity 86: $1112-25$.

Khalidi, L., B. Gratuze \& S. BoucetTa. 2009. Provenance of obsidian excavated from the Late Chalcolithic levels at the sites of Tell Hamoukar and Tell Brak, Syria. Archaeometry 51: 879-93. http://dx.doi.org/10.1111/j.1475-4754. 2009.00459.x
LAWRENCE, D. 2012. Early urbanism in the northern Fertile Crescent: a comparison of regional settlement trajectories and millennial landscape change. Unpublished PhD dissertation, Durham University.

LaWrence, D., J. Bradbury \& R. Dunford. 2012. Chronology, uncertainty and GIS: a methodology for characterising and understanding landscapes of the ancient Near East, in W. Bebermeier, R. Hebenstreit, E. Kaiser \& J. Krause (ed.) Landscape archaeology. Proceedings of the International Conference held in Berlin, $\sigma^{\text {th }}-8^{\text {th }}$ June 2012 (Journal for Ancient Studies Special Volume 3): 353-59. Berlin: Excellence Cluster Topoi.

MCCorriston, J. 1997. The fiber revolution: textile extensification, alienation, and social stratification in Ancient Mesopotamia. Current Anthropology 38: 517-35. http://dx.doi.org/10.1086/204643

McInTOSH, S.K. 1999. Pathways to complexity: an African perspective, in, S.K. McIntosh (ed.) Pathways to complexity in Africa: 1-30. Cambridge: Cambridge University Press.

McMahon, A., A. Soltysiak \& J.A. Weber. 2011. Late Chalcolithic mass graves at Tell Brak, Syria, and violent conflict during the growth of early city-states. Journal of Field Archaeology 36: 201-20. http://dx.doi.org/10.1179/ 009346911 X12991472411123

MeYER, J.-W. 2007. Town planning in third millennium Tell Chuera, in J. Bretschneider, J. Driessen \& K. Van Lerberghe (ed.) Power and architecture: monumental public architecture in the Bronze Age Near East and Aegean: proceedings of the international conference "Power and Architecture": 129-42. Leuven: Peeters.

NishimurA, Y. 2008. North Mesopotamian urban space: a reconstruction of household activities and city layout at Titriş Höyük in the third millennium BC. Unpublished PhD dissertation, Los Angeles University of California.

PFÄlZnER, P. 2010. Introduction and synthesis: urban development and ecology at Tell Mozan, in K. Deckers, M. Doll, P. Pfälzner \& S. Riehl (ed.) Development of the environment, subsistence and settlement of the city of Urkesh and its region: 1-12. Wiesbaden: Harrassowitz.

ReICHEL, C.D. 2009. Beyond the Garden of Eden-competition and early warfare in northern Syria (4500-3000 B.C.). Schlachfeldarchäologie 2: 17-30.

ReY, S. 2012. Poliorcétique au Proche-Orient ancien. Fortifications urbaines, procédés de siège et systèmes défensifs (aux origines de l'art de prendre et de défendre les villes). Beirout: IFPO. 
RistVET, L. 2011. Travel and the making of north Mesopotamia polities. Bulletin of the American Schools of Oriental Research 361: 1-31.

Rothman, M.S. 2001. Uruk Mesopotamia and its neighbours: cross-cultural interactions in the era of state formation. Santa $\mathrm{Fe}(\mathrm{NM})$ : School of American Research Press.

SCHACT, R.M. 1984. The contemporaneity problem. American Antiquity 49: 678-95. http://dx.doi.org/10.2307/279736

SCHWARTZ, G. 1988. A ceramic chronology from Tell Leilan Operation 1. New Haven (CT): Yale University Press.

- 2001. Syria and the Uruk expansion, in M.S. Rothman (ed.) Uruk Mesopotamia and its neighbours: 233-64. Santa Fe (NM): School of American Research Press.

Sertok, K., F. KulakoĞLu \& F. SQuadrone. 2007. Living along and together with the Euphrates. The effects of the Euphrates on a long-life settlement such as Şaraga Höyük, in C. Marro \& C. Kuzucuoğlu (ed.) Sociétés humaine et changement climatique à la fin du troisième millénaire: une crise a-t-elle eu lieu en Haute Mésopotamie?: 341-53. Paris: De Boccard.

SMITH, M.E. 2007. Form and meaning in the earliest cities: a new approach to ancient urban planning. Journal of Planning History 6(1): 3-47. http://dx.doi.org/10.1177/1538513206293713

SMith, S., T.J. Wilkinson \& D. LAWRENCE. 2014. Agro-pastoral landscapes in the zone of uncertainty: the Middle Euphrates and the north Syrian steppe during the $4^{\text {th }}$ and $3^{\text {rd }}$ millennia BC, in D. Morandi Bonacossi (ed.) Settlement dynamics and human-landscape interaction in the dry steppes of Syria (Studia Chaburensia 4): 151-72. Wiesbaden: Harrassowitz.

STEIN, G. 2004. Structural parameters and sociocultural factors in the economic organisation of north Mesopotamian urbanism in the third millennium BC, in G. Feinman \& L. Nicholas (ed.) Archaeological perspectives on political economies: 79-104. Salt Lake City: University of Utah Press.

- 2012. The development of indigenous social complexity in Late Chalcolithic Upper Mesopotamia in the $5^{\text {th }}-4^{\text {th }}$ millennia BC-an initial assessment. Origini 34: 125-51.

UR, J. 2010a. Cycles of civilisation in northern Mesopotamia, 4400-2000 BC. Journal of Archaeological Research 18: 387-431. http://dx.doi.org/10.1007/s10814-010-9041-y

- 2010b. Urbanism and cultural landscapes in northeastern Syria: the Tell Hamoukar survey, 1999-2001. Chicago (IL): Oriental Institute.
Ur, J., P. KarsgaArd \& J. OATes. 2011. The spatial dimensions of early Mesopotamian urbanism: the Tell Brak suburban survey. Iraq 73: 1-19.

VAN DE MiEROOP, M. 2007 [1997]. A history of the ancient Near East, 3000-323 BC. Malden: Blackwell.

WeIss, H. 1997. Late third millennium abrupt climate change and social collapse in West Asia and Egypt, in H. Dalfes, G. Kukla \& H. Weiss (ed.) Third millennium BC climate change and Old World collapse: 711-23. Berlin: Springer. http://dx.doi.org/10.1007/978-3-642-60616-8_33

Wilkinson, T.J. 1994. The structure and dynamics of dry-farming states in Upper Mesopotamia. Current Anthropology 35: 483-520. http://dx.doi.org/10.1086/204314

Wilkinson, T.J., C. French, J. Ur \& M. Semple. 2010. The geoarchaeology of route systems in northern Syria. Geoarchaeology 25(6): 745-71. http://dx.doi.org/10.1002/gea.20331

Wilkinson, T.J., N. Galiatsatos, D. LaWREnCe, A. Ricci, G. Philip \& R. Dunford. 2012. Late Chalcolithic and Early Bronze Age landscapes of settlement and mobility in the Middle Euphrates: a reassessment. Levant 44: 139-85.

http://dx.doi.org/10.1179/ 0075891412Z.0000000007

Wilkinson, T.J., G. Philip, J. Bradbury, R. Dunford, D. Donoghue, N. Galiatsatos, D. LaWrence, A. Ricci \& S. Smith. 2014. Contextualizing early urbanization: settlement cores, early states and agro-pastoral strategies in the Fertile Crescent during the fourth and third millennia BC. Journal of World Prehistory 27: 43-109. http://dx.doi.org/10.1007/s10963-014-9072-2

WoOLley, C.L. 1934. The prehistoric pottery of Carchemish. Iraq 1: 146-62.

Wossink, A. 2009. Challenging climate change: competition and cooperation among pastoralists and agriculturalists in northern Mesopotamia (c. 3000-1600 BC). Leiden: Sidestone.

YOFFEE, N. 2005. Myths of the archaic state. Evolution of the earliest cities, states and civilizations. Cambridge: Cambridge University Press. http://dx.doi.org/10.1017/CBO9780511489662

ZeTTLER, R. 1997. Introduction, in R. Zettler (ed.) Subsistence and settlement in a marginal environment: Tell es-Sweyhat, 1989-1995 preliminary report: 1-10. Philadelphia: University of Pennsylvania Museum of Archaeology and Anthropology.

Received: 20 February 2014; Accepted: 19 May 2014; Revised: 22 September 2014

(C) Antiquity Publications Ltd, 2015 